\title{
Planning for change? Assessing the integration of climate change and land-based livelihoods in Colorado BLM planning documents
}

\author{
Julia Nave ${ }^{1}\left[\right.$ C Corrine Noel Knapp ${ }^{2} \cdot$ Shannon McNeeley ${ }^{3}$
}

Received: 8 January 2019 / Accepted: 16 January 2020 / Published online: 19 February 2020

(C) The Author(s) 2020

\begin{abstract}
Many western communities are surrounded by public lands that support land-based and local economies. Bureau of Land Management (BLM) decision-making affects the vulnerability of those land-based livelihoods, especially in the context of climate change. We analyzed Colorado BLM planning documents to evaluate how they are considering climate change, sensitive resources, impacts, and land-based livelihoods in their planning processes using both quantitative word counts and qualitative coding. Documents published in recent years (2011-2015) include more mentions of climate change than older documents (1985-1997). However, the review showed that while climate change is discussed within the National Environmental Policy Act (NEPA) planning documents, the final Resource Management Plans contain few mentions of climate change. Further, there is minimal consideration of how climate change may impact land-based livelihoods. These results prompt questions about the planning process, how climate change considerations are integrated into the final documents, and how that impacts on-theground management. The review suggests a need for increased consideration of climate change throughout the BLM's planning process so that landscapes can be managed with more attention and awareness to climate change and the associated impacts to resources and dependent communities.
\end{abstract}

Keywords Land-based livelihoods $\cdot$ Climate change $\cdot$ BLM $\cdot$ Gray literature $\cdot$ Planning $\cdot$ NEPA

\section{Introduction}

In the Western USA, changes in climate have introduced a suite of impacts that are projected to increase in frequency

Communicated by Debbie Ley

Electronic supplementary material The online version of this article (https://doi.org/10.1007/s10113-020-01590-0) contains supplementary material, which is available to authorized users.

Julia Nave

Julia.cc.nave@gmail.com

Corrine Noel Knapp

corrie.knapp@uwyo.edu

Shannon McNeeley

shannon.mcneeley@colostate.edu

1 Western Colorado University, Gunnison, Colorado, USA

2 Haub School of Environment \& Natural Resources, University of Wyoming, Laramie, Wyoming, USA

3 Natural Resource Ecology Laboratory, Colorado State University, Fort Collins, Colorado, USA and severity in the future, including drought, forest fire, and flooding (Gordon \& Ojima 2015; Gonzalez et al. 2018; Reidmiller et al. 2018). These impacts pose a challenge to public land management agencies, who manage an average of $48.3 \%$ of the land in each of the 12 western states (Vincent et al. 2017), and the people whose livelihoods are dependent upon federal lands (Gordon \& Ojima 2015; Kemp et al. 2015). For instance, US Forest Service (USFS) firefighting budget has gone from $16 \%$ of their annual budget in 1995 to over 50\% in 2015 (US Forest Service (USFS), 2015), and Bureau of Land Management (BLM) permitted livestock authorizations dropped from over 18 million animal unit months (AUMs ${ }^{1}$ ) in 1953 to about 8 million in 2014 due in part to the impact of drought on rangeland health (Wiles \& Warren 2016). It is also possible that climate-driven changes could have positive effects on resources and livelihoods in some places, for instance, increased visitation to high-elevation, cool places during heat waves in lower elevations. Since

\footnotetext{
${ }^{1}$ Animal unit month (AUM) is defined as the forage needed for one "animal unit" for 1 month. An "animal unit" is considered a 1000-lb cow and her suckling calf. AUM is the unit used to calculate federal grazing fees by the BLM.
} 
these changes directly influence ranching and recreationbased businesses, it is important for multiple-use agencies to consider how climate change will influence social and ecological vulnerability (Archie et al. 2012; Eakin \& Luers 2006; McNeeley et al. 2017a). In this study, we explore how the BLM in Colorado is currently integrating climate change into planning documents, what types of climate-sensitive resources and impacts are discussed, and how impacts to landbased livelihoods are being addressed.

Recognizing the need and urgency to address climate change on our nation's public lands, the Department of the Interior (DOI) issued mandates (in 2001 and 2009) and various executive orders (in 2009, 2013, and 2015) that directed agencies to integrate climate change into their planning and management (Department of Interior (DOI), 2009; Executive Order (EO), 2009, 2013, 2015). However, it is unclear if these orders have successfully brought climate change to the forefront of planning discussions at the state or field office level as intended (Kemp et al. 2015), and we seek to address this through our analysis. In 2017, President Trump removed the threat of climate change from his National Security Strategy and withdrew from the Paris Agreement in 2017 (Shear 2017; Trump 2017), and the DOI Strategic Plan for 2018-2022 contains no mentions of climate change (Department of Interior (DOI), 2018a). Despite a lack of active climate change-related policy from the current administration, the reality of climate change will require action in the future (Reidmiller et al. 2018).

The multiple-use mission of the BLM directs the agency to steward 248 million acres of public land for a variety of uses, such as energy development, livestock grazing, recreation, and minerals (Federal Land Policy Management Act (FLPMA) of 1976, 1976; Vincent et al. 2017). While the mission exists at the federal level under the Federal Land Policy Management Act (FLPMA), management direction at the field office level is established through Resource Management Plan (RMP). These documents form the basis for every management action and approved use on BLM lands (Bureau of Land Management (BLM), 2016). They set goals and objectives, assign protection to key resources, determine appropriate uses, and establish monitoring systems to evaluate health of resources and effectiveness of management practices over time. The RMPs are developed by each field office for their planning area and are meant to last for 20-30 years before revision (Bureau of Land Management (BLM), 2016). The drafting and approval of a new plan requires an Environmental Impact Statement (EIS).

Many resources that the BLM manage are sensitive to the potential impacts of climate change such as drought, severe fire, changes in precipitation, and extreme weather events (Executive Order (EO), 2013; Gonzalez et al. 2018). To continue to support multiple uses, the agency will need to adapt their management strategies (e.g., season or duration of grazing use) to respond to the emerging effects of climate change across the landscape (Department of Interior (DOI), 2009). If RMPs fail to consider potential climate change impacts or responses, they may be unprepared and unresponsive.

The aim of this study is to improve our understanding of how climate change has been considered by the BLM field offices in Colorado. In this paper, we analyzed planning documents to assess how climate change is being integrated, what types of climate-sensitive resources and climate-related impacts are addressed, and whether the vulnerability of landbased livelihoods is considered in the context of climate change. This study was part of a larger social vulnerability assessment (SVA) that included a statewide geospatial analysis and two field office case studies that used interviews to explore statewide land usage patterns, community connections to public lands, and the vulnerability of people with land-based livelihoods to changes in public land resources. Together, the mixed methodologies provide an integrated and holistic look at climate-related vulnerability on Colorado BLM lands (McNeeley et al. 2017b). In this paper, we report on the document review.

\section{Methods}

To assess how the Colorado BLM has considered climate change, we reviewed the most recent planning documents $(N=22)$ from each of the ten field offices (Fig. 1) and meeting notes from the three Resource Advisory Councils (RAC) $(N=$ $60)$, together referred to as the "gray literature" (Online Resource 1). These documents are publicly available and housed on the Colorado BLM website. Documents were uploaded and coded in NVivo, a qualitative analysis software. Our goal was not to compare across field offices, but to understand when and how climate change was being discussed.

When a new RMP is proposed for a field office planning area, a final Environmental Impact Statement (FEIS) is published with it per the National Environmental Policy Act (NEPA). After a 30-day protest period and any necessary revisions, the final RMP is published with a Record of Decision (ROD). Therefore, each field office has a proposed RMP accompanied by the final EIS (PRMP/FEIS) and a final RMP (Fig. 2). In Colorado, the publishing/approval date on these documents ranges from 1985 to 2015 . The more recent documents are significantly longer than the older documents. For example, the six PRMP/FEIS published before 2000 average 337 pages, while the five published after 2000 average 2421 pages. Since we are interested in whether and how documents are mentioning climate change, and not how intensively they address it, we do not correct for relative abundance. A total of 18,533 pages of planning documents were analyzed.

RACs, established in 1995, are citizen-based groups that consist of 10 to 15 user group representatives. The Colorado 
Fig. 1 The Bureau of Land Management, an agency within the Department of Interior, has ten field offices in Colorado. These field offices each fall under a regional district and each develop Resource Management Plans to guide their management. Each regional district also has a Resource Advisory Council, a citizen-based group of user representatives that weigh in on management decisions

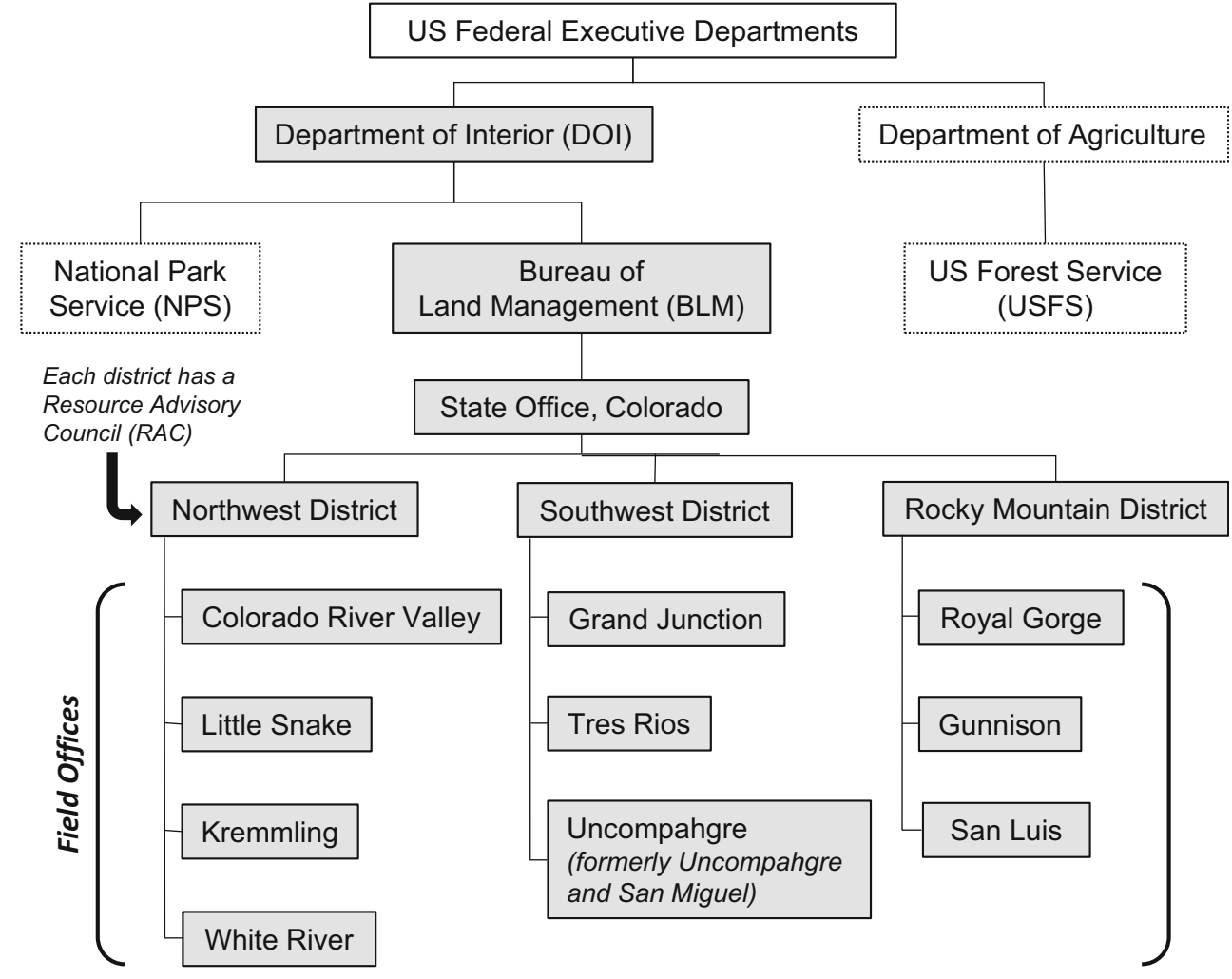

field offices are grouped into three districts that each have a RAC: Rocky Mountain (previously Front Range), Northwest, and Southwest. In their approximately four annual meetings, they develop and vote on recommendations related to public land management and land-use planning (Bureau of Land Management, 2017a). Meeting minutes/notes are posted online and were compiled from 2010 to 2019. This resulted in 18 meeting notes from the Rocky Mountain RAC, 25 meeting notes from the Northwest RAC, and 17 meeting notes from the Southwest RAC. Over 500 pages of RAC notes were analyzed.

Five steps were taken to analyze the documents and assess how climate change was being integrated into planning processes:

\section{Developed search terms}

In addition to the words "climate change," we were interested to see how different climate-sensitive resources, climaterelated impacts, and livelihoods might be discussed along with climate change. We assembled variations of the term "climate change" to search for explicit mentions throughout the documents and developed a list of associated impact, resource, and livelihood terms to identify passages where these terms overlap with climate change. We decided to focus on explicit mentions of climate change since it would be very subjective to guess whether passages about impacts or resources were meant to refer to climate change. Examples of climaterelated impacts include "fire" and "drought." Examples of climate-sensitive resources include "vegetation" and "water." Livelihood terms included "ranching" and "recreation." A complete list of terms is included in Online Resource 2.

\section{Coded documents}

Using NVivo, we conducted a text search for each term and then coded that word as a "node." Creating a "node" effectively flags and saves each occurrence of that term in the documents so it can be referenced in the text when performing analysis in later steps. The "nodes" allowed us to look for
Fig. 2 The revision of a Resource Management Plan is a multi-year process that involves opportunities for the public to participate. The documents in solid boxes are the planning documents we reviewed in this study

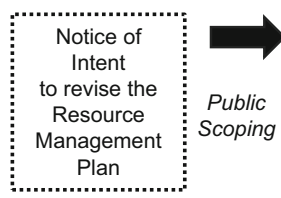

\begin{tabular}{|c|}
\hline Proposed \\
Resource \\
Management \\
Plan \\
$\&$ \\
Final \\
Environmental \\
Impact \\
Statement \\
(PRMP/FEIS) \\
\hline
\end{tabular}

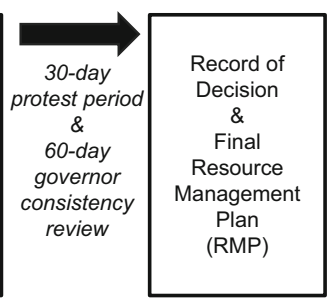


emerging patterns across the documents and quickly find points of interest in the text.

\section{Coded explicit climate change passages}

Each explicit mention of climate change was visited to explore the context of the passage. The passage surrounding the explicit mention of climate change was coded and saved as a new "node." Highlighting whole passages (1-3 sentences) allowed us to determine overlap with other terms in the following steps.

\section{Analyzed with code matrices}

Once all documents were coded with terms and passages containing explicit mention of climate change, a series of "code matrices" were created to examine climate-relevant passages more deeply. The "code matrix" feature in NVivo allows the researcher to find co-occurrences of terms or passages (Online Resource 3). In our case, matrices were used to look at overlap between (1) livelihood terms and explicit mention of climate change, (2) climate-related impact terms and explicit mention of climate change, and (3) climate-sensitive resource terms and explicit mention of climate change.

\section{Qualitative analysis}

Finally, we explored each instance of overlap between our livelihood terms and passages with explicit mention of climate change to better understand how livelihoods were mentioned in the context of climate change.

\section{Results}

\section{Explicit mention of climate change}

"Climate change(s)," "climatic change(s)," or "changes to climate" were considered explicit mentions of climate change in the analysis of the gray literature. Searching these terms gives us a sense of whether the Colorado BLM is currently discussing climate change. These terms occurred in the field office planning documents a total of 720 times and in the RAC notes only 12 times. Only one field office, Tres Rios, mentions climate change in the body of the RMP $(N=4)$. However, all 2015 RMPs $(N=4)$ mention climate change in their appendices, totaling 83 mentions across RMPs. The five field offices that revised their RMP most recently (2011 and 2015) mention climate change a total of 637 times in their PRMP/FEIS (Table 1).

Climate change was rarely mentioned $(N=13)$ in RAC meeting notes. The Southwest RAC mentioned climate change a total of 8 times over three occasions. The
Northwest RAC mentioned climate change three times and the Rocky Mountain RAC mentioned climate change twice. Most of the climate change mentions in RAC notes were included in the lists of future discussion topics, as potential field trips, or in updates about ongoing projects and partnerships. However, on two occasions, climate change was mentioned within a discussion about RMP revisions. During an RMP revision Q\&A at the February 2013 Rocky Mountain RAC meeting, a BLM representative stated that "climate change is a new concept for many RMPs and should be addressed." In the May 2012 Northwest RAC meeting, a RAC member asked about how the BLM will handle addressing both climate change and coal extraction in an RMP revision. Although the RAC notes do not grapple extensively with climate change, they do hold evidence that climate change has been mentioned during some RMP revisions.

\section{Climate-sensitive resources and climate-related impacts}

We used a coding matrix to explore which climate-sensitive resources and potential climate-related impacts are commonly discussed in the context of climate change. The quantitative result is a count of the number of times a certain term is mentioned in a passage with climate change (Table 2). Climate-sensitive resource terms were mentioned a total of 578 times in the context of climate change. Terms most commonly mentioned with explicit climate change were those related to water or hydrology $(N=341 ; 59 \%$ of total $)$. "Vegetation" $(N=232)$ and "forage" $(N=8)$ were the only other resources mentioned. Most frequent impacts were "drought" $(N=109)$ and "fire" $(N=94)$.

\section{Land-based livelihoods and climate change}

A coding matrix was also employed to target the overlap between livelihood terms and explicit mentions of climate change. Examples of this overlap are mostly in PRMP/FEIS documents, with a couple of examples from RMP appendices, and none within the RAC meeting notes. The livelihood terms used could be grouped into three categories: ranching, recreation, and tribal. Ranching and recreation were examined due to their high dependence upon ecosystem services provided by BLM-managed lands (Knapp et al., 2011; Lukas et al. 2014) and their economic importance in rural parts of the state (Bureau of Land Management (BLM), 2015). Tribal terms were included because there are two federally recognized tribes with reservations in Colorado and over 45 tribes with historic ties to the state's public lands (State of Colorado 2017). Ranching terms had the greatest overlap with climate change discussions $(N=120)$. This included 109 mentions of "grazing" and "livestock," six mentions of "ranch(-ing)," two 
Table 1 Explicit mentions of climate change across field office Proposed Resource Management Plans/Final Environmental Impact Statements (PRMP/FEIS) and final Resource Management Plans (RMP) with Record of Decision

\begin{tabular}{|c|c|c|c|c|c|}
\hline \multirow[b]{2}{*}{ Field office } & \multirow[b]{2}{*}{$\begin{array}{l}\text { Year RMP } \\
\text { published }\end{array}$} & \multicolumn{4}{|c|}{ Counts of explicit climate change } \\
\hline & & $\begin{array}{l}\text { Proposed RMP } \\
\text { and FEIS }\end{array}$ & $\begin{array}{l}\text { PRMP and FEIS } \\
\text { appendices }\end{array}$ & $\begin{array}{l}\text { Final } \\
\text { RMP }\end{array}$ & $\begin{array}{l}\text { RMP } \\
\text { appendices }\end{array}$ \\
\hline Colorado River Valley & 2015 & 125 & 39 & 0 & 2 \\
\hline Grand Junction & 2015 & 78 & 0 & 0 & 28 \\
\hline Kremmling & 2015 & 300 & 5 & 0 & 3 \\
\hline Tres Rios & 2015 & 40 & N/A & 4 & 46 \\
\hline Little Snake & 2011 & 42 & 8 & 0 & 0 \\
\hline White River & 1997 & 0 & 0 & 0 & 0 \\
\hline Royal Gorge & 1996 & 0 & 0 & 0 & 0 \\
\hline Gunnison & 1993 & 0 & 0 & 0 & 0 \\
\hline San Luis Valley & 1991 & 0 & 0 & 0 & 0 \\
\hline Uncompahgre Basin & 1989 & 0 & 0 & 0 & 0 \\
\hline $\begin{array}{l}\text { San Juan and San Miguel } \\
\text { (now Uncompahgre) }\end{array}$ & 1985 & 0 & 0 & 0 & 0 \\
\hline Total & & \multicolumn{2}{|c|}{637} & & 83 \\
\hline
\end{tabular}

mentions of "permittee(s)," and one mention of "AUM" (animal unit month).

Recreation terms followed $(N=64)$ with the word "recreation" account for 55 of the 64 counts. "Hunt(-ing)" $(N=5)$, "fishing" $(N=3)$, and "rafting" $(N=1)$ are the only other recreation terms mentioned within climate change passages. Tribal terms only overlapped once with explicit climate change passages and it was the word "tribal." Livelihood terms that never occurred in the context of climate change include biking, boating, guiding, hiking, skiing, special event, wildlife viewing, indigenous, Kiowa, Native American, and Ute.

Table 2 Numbers of climate-sensitive resource and climate-related impact terms found in passages explicitly discussing climate change

\begin{tabular}{llll}
\hline Climate-sensitive resources & 578 & Climate-related impacts & 294 \\
\hline Water-related terms & 341 & Drought & 109 \\
Water & 182 & Fire & 94 \\
River & 55 & Disease & 28 \\
Precipitation & 35 & Insect & 26 \\
Runoff & 19 & Flood & 20 \\
Snow & 16 & Weather & 11 \\
Snowpack & 11 & Extreme weather & 5 \\
Stream flow & 9 & Beetle & 4 \\
Soil moisture & 7 & Heat waves & 2 \\
Evaporation & 3 & & \\
Water availability & 2 & & \\
Hydrograph & 1 & & \\
Annual precipitation & 1 & & \\
Vegetation & 232 & & \\
Forage & 8 & & \\
\hline
\end{tabular}

While livestock/grazing is mentioned frequently with explicit climate change, most of this overlap does not actually represent a discussion of the vulnerability of these livelihoods. Forty-eight percent of the occurrences of overlap simply point to passages where "livestock grazing" and "climate change" are listed together in a repetitive format. Nearly all examples of this are when they are listed under multiple alternatives as "impacts from management actions and allowable uses" that will have "negligible impacts" on a resource.

Since these 57 passages are not targeting an interaction between grazing and climate change, they will not be discussed further. In the remaining 46 passages, roughly half of "grazing" mentions $(N=24)$ with climate change occur in passages where both are being listed as threats or stressors to a resource or where it is said that livestock grazing may exacerbate the impacts of climate change or vice versa. For example, the following quote shows how livestock grazing is listed as a stressor that may impact a resource's ability to adapt to climate change:

"Climate change would impact soil resources under all alternatives, but soil resources may be more vulnerable to the impacts of climate change under certain alternatives. Resource uses in the planning area (e.g., livestock grazing, forestry, recreation, travel ... ) are stressors that may generally impact soil's ability to adapt to climate change."

This same statement is repeated, replacing "soil" with other resources such as "water," "fish and wildlife," and "vegetation." Note that "recreation" is also listed as a stressor in this passage. Additionally, there are 12 examples of passages where ranching is discussed as a contributor to climate change through greenhouse gas (GHG) production associated with the industry. These examples illustrate how passages primarily consider livestock grazing as a threat, stressor, and contributor to climate change. Livestock grazing is discussed as effected 
by climate change in only 10 passages. The Kremmling Field Office notes in their PRMP/FEIS:

"These areas show the vulnerability of the rangelands to drought and climate change, and adaptive management is essential to ensure sustainable soil health. It is difficult for permittees to respond to short notice changes; therefore, monitoring of trends is important in order to increase the lead time."

In this passage, the vulnerability of rangelands is acknowledged as is the challenge of short response time on the part of the permittees. While they do not cite specific monitoring thresholds or targets, their suggestion to use monitoring to inform adjustments to management suggests that inclusion of such thresholds or targets in planning documents and/or in practice may be possible.

Recreation is discussed similarly in the context of climate change. Kremmling, Grand Junction, and Colorado River Valley PRMP/FEIS documents all mention the word "recreation" in passages with climate change, but only 3 of the 55 mentions acknowledge the effect climate change could have on recreation. These passages recognize that changes in the timing of snowmelt and overall water availability will impact recreation, but they do not explore any specific trends or management options. Grand Junction PRMP/FEIS states:

"Predicted climate change impacts in Colorado may include earlier melting of snowpack, lower river flows in summer months, water shortages for irrigated agriculture, slower recharge of groundwater aquifers, effects on water availability for recreation and wildlife use, and migration of plant and animal species to higher elevations."

More frequently, the word "recreation" is either listed along with climate change as a potential threat or stressor to a resource $(N=19)$ or, occasionally in the case of "motorized recreation," it is listed as a producer of GHG and a contributor to climate change $(N=4)$.

In the Kremmling PRMP/FEIS, there are examples where "climate change" is listed under a proposed plan or alternative to have a "negligible impact to recreation uses and visitor services" $(N=5)$ and vice versa $(N=5)$. These 10 passages represent a third of the total climate change and recreation overlap quantified in the Kremmling PRMP/FEIS. This is an illustration of how Colorado BLM planning documents do not commonly explore the connections between climate change impacts and land-based livelihoods and an example of the often-formulaic nature of these documents.

\section{Discussion}

In this section, we discuss how planning documents (1) consider climate change, which (2) climate-sensitive resources and (3) climate-related impacts are most frequently considered in the context of climate change, and (4) how livelihoods and climate change are discussed together.

\section{Climate change inclusion in planning documents}

Climate change is rarely discussed openly in the final versions of field office RMPs. According to the BLM, the RMPs guide their management efforts and "serve as blueprints for sustaining the health, ecological diversity, and productivity of the public lands" (Bureau of Land Management (BLM), 2016). Thus, it is interesting that they would not include climate change to a greater degree as something that threatens public land health, ecological diversity, and productivity. The 2015 final RMPs $(N=4)$ that include references to climate change mostly do so in the appendices rather than integrating it throughout the document. The discussion surrounding climate change in these cases is an acknowledgment rather than an indepth exploration of impacts.

Climate change is more directly and thoroughly addressed in the PRMP/FEIS documents. There are higher counts of "climate change" and, in some cases, whole sections that systematically explore "air" or "climate" as a resource that would be affected by the proposed plan. In the Kremmling and Colorado River Valley PRMP/FEIS, climate change is addressed in the "Resources" section of the "Affected Environment" and "Environmental Consequences" chapters. However, they approach the topic primarily from a GHG mitigation angle. In these sections, the BLM defines climate change as an issue, cites global trends and projections, identifies some potential impacts to resources, and attempts to inventory how much the plan might contribute to climate change. Discussion about possible adaptation measures or management actions in response to the associated impacts is rare, but examples include mentioning that fuel treatments and prescribed burns "could increase in the future" due to an increase in severity and frequency of wildfires, as well as a brief discussion of maintaining and promoting old-growth forest habitat because "they have survived under changing conditions" and, therefore, "may contain genes that would enable them to survive global climate change ..." (Colorado River Valley PRMP/FEIS).

The difference in climate change inclusion between the PRMP/FEIS document the final ROD and RMP is due, in part, to the fact that the NEPA documents analyze impacts while the RMP focuses on management decisions based on those impacts. Discussions of impacts that occur in preliminary stages of the RMP and NEPA process are generally removed from the final document, with both versions being publicly available. However, the lack of clear connection between impacts and management responses in the planning document (RMP) still raises questions, since these documents present management guidance for the coming decades. Below, we explore three factors that likely influence the inclusion of climate change in the documents assessed: (1) the release of climate change guidance for the NEPA process from the White House Council on Environmental Quality (CEQ), (2) 
the difficulty of incorporating adaptive management, and (3) politics surrounding climate change.

\section{White House guidance}

The inclusion of climate change in the 2011 and 2015 PRMP/ FEIS documents followed guidance issued from the White House CEQ. The guidance was proposed in 2010, revised in 2014, finalized in 2016, and rescinded in 2017. The purpose was to provide guidance to federal agencies on how to consider the impacts of their actions on climate change in their NEPA reviews. Specifically, the CEQ guidance assists federal agencies and departments with considering " 1 ) the potential effects of a proposed action on climate change as indicated by assessing GHG emissions and 2) the effects of climate change on a proposed action and its environmental impacts" (Council on Environmental Quality (CEQ), 2016). Focusing on GHG emissions allows agencies to compare the emissions generated by each plan alternative and their relative contribution to climate change. This guidance shifted the way that climate change is included in the PRMP/FEIS documents from 2015. The 2015 documents define the issue of climate change and describe some of the potential impacts to the land. An example of this acknowledgment of impacts comes from the Kremmling PRMP/FEIS: "If predicted climate changes occur, BLM-managed public lands could have less snowpack, which could, in turn, result in drier rangeland conditions and less snowmelt-fueled runoff that feeds streams, recharges springs, and fills stockwater ponds and reservoirs. Water sources on public lands might also be reduced in response to climate change or drought."

In this example and others, the BLM recognizes and describes a potential impact of climate change, but this language is rarely accompanied by a management strategy or plan. Despite the CEQ guidance, several PRMP/FEIS documents state that it is still challenging to understand impacts of climate change at a local level and how local level activities influence climate change. For example, Grand Junction PRMP/FEIS states: "Tools to analyze or predict how global or regional climate systems may be affected by a particular activity or activities within the planning area are not currently available."

While there are a few examples of thoughtful and unique passages relating to climate change, many occur in a more formulaic and repetitive manner. "Climate change" is often included in a list of threats to a species or resource, but the specifics of these relationships are not always expanded upon. This shows how climate change is considered in relation to various resources, but how there is often not a lot of detail about the planning implications. For example, the following phrase is repeated for several resources, substituting "special status species" for "vegetation" and "water," etc.: "Climate change would impact special status species under all alternatives, but special status species may be more vulnerable to the impacts of climate change under certain alternatives." (Grand Junction PRMP/FEIS).

The CEQ guidance focused on GHG mitigation rather than adaptation to the impacts because the EIS is meant to evaluate environmental impacts of management alternatives. Because this guidance only pertains to the NEPA process and evaluation of alternatives, we do not see mentions of climate change, or responses to it, carried over into the final RMP.

\section{Challenges in incorporating adaptive management}

Adaptive management (AM) is an iterative process that relies upon ongoing monitoring to make management decisions in the face of uncertainty (Holling 1978). It has been proposed as a strategy to allow agencies to adapt to complex challenges such as climate change. However, NEPA regulations require analysis of specific management alternatives and their environmental impacts. This often leads to RMPs that provide set management prescriptions instead of adaptive guidelines. A variety of possible ways to incorporate AM in the NEPA process have been explored (Canter \& Atkinson 2010) and a few precedents exist (US Forest Service (USFS), 2016; US Forest Service (USFS), 2017). In our gray literature analysis, we observed passages where the Colorado BLM plans for variability and discusses potential management outcomes. One example, found in the Grand Junction PRMP/FEIS, was of adaptive drought management where specific management actions, adjustments, or restrictions would be implemented for each pre-defined level of drought severity. The challenge of incorporating AM in planning that goes through NEPA is not unique to the BLM, and other public land agencies have recently had success integrating flexibility into their planning processes. In the USFS, the Spruce Beetle Epidemic and Aspen Decline Management Response (SBEADMR) Project is currently being carried out by the GMUG National Forests in Colorado (US Forest Service (USFS), 2016). The adaptive framework of the project allows the USFS to respond dynamically to spruce beetle outbreaks and adapt their management to efficiently respond to monitoring data. Examples of threshold-based AM exist in both USFS and National Park System (NPS) recreation planning. The 2013 Yellowstone National Park Winter Use Plan EIS and the 2017 Maroon Bell-Snowmass Wilderness Area Overnight Visitor Use Management Plan Environmental Assessment (EA) in White River National Forest both define thresholds related to visitor use so they may respond quickly to reduce resource damage (National Park Service (NPS), 2016; US Forest Service (USFS), 2017). While these are not the agency equivalent of an RMP (i.e., USFS Forest Plan), they nevertheless serve as examples of instances where AM language has made it through the NEPA process. 


\section{Politics of climate change}

Finally, the political nature of climate change is a factor that influences the integration of climate change into RMPs. From the federal administration, down to the field offices and user groups on the land, climate change is often a disputed and politically charged issue, which was apparent in case studies that complemented this study where field office employees described how politics and a lack of top-down leadership limited the inclusion of climate change in planning (see McNeeley et al. 2017b). Planners may have integrated climate change by discussing less controversial impacts such as drought and fire. If so, they are addressing some of the climate change-related impacts without drawing a direct link to climate change. While this approach addresses some of the potential effects of climate change, it would also be beneficial to acknowledge the variety of ways these impacts may intensify because of climate change.

\section{Climate change inclusion in RMP documents}

The authors believe that the lack of climate change inclusion in RMP documents is not attributed to a single reason, but likely a combination of all the previously discussed factors. In contrast, other federal land agencies, such as the USFS and NPS, have prioritized climate change in their planning processes to a greater degree (Archie et al. 2012). The NPS is also housed under the DOI, but is focused on conservation. Their Climate Change Response Strategy served as an urgent call to action on climate change (National Park Service (NPS), 2010), and their Climate Change Action Plan proposed specific actions within eight emphasis areas, including integrating climate change into planning (National Park Service (NPS), 2012). The USFS is housed under the Department of Agriculture and is also a multipleuse land agency. The Chief of the USFS established 16 high priority actions to address climate change in 2008. Two of the actions were to "provide guidance for field units on how to treat climate change in project planning and NEPA documents" and "provide guidance for field units on how to treat climate change in forest plan revision" (US Forest Service (USFS), 2009). This directive was followed by two published guidance documents in 2009 and 2010: Climate Change Considerations in Land Management Plan Revisions and Climate Change Considerations in Project Level NEPA Analysis (US Forest Service (USFS), 2009). The guidance documents are brief (under 10 pages) and outline principles specifically for incorporating climate change into agency planning documents. These guidance documents published by other federal land agencies serve as examples of how the BLM could prioritize and integrate climate change in RMP revisions.

\section{Climate-sensitive resources}

We assessed which resources were considered in passages where climate change was explicitly mentioned. The most prevalent resource was water-related terms, highlighting the importance of water and hydrologic systems in Colorado. As a semi-arid state with a statewide average of $17 \mathrm{in.} \mathrm{of} \mathrm{annual} \mathrm{precipitation,} \mathrm{Colorado} \mathrm{is} \mathrm{the} \mathrm{seventh}$ driest state in the country (Frankson et al. 2017). Snowmelt from mountain regions serves as the primary source of water in streams and rivers through the summer months and provides $70 \%$ of the state's surface water. Colorado is home to the headwaters of four major river systemsthe Arkansas, Rio Grande, Platte, and Colorado- that produce 15 million acre feet of water annually (US Geological Survey (USGS), 1990). Since climate change projections suggest continuing shifts in Colorado's precipitation regime (Lukas et al. 2014), examining how these hydrologic resources may change is critical to ensure a secure water supply for the future. From a BLM planning perspective, water is a critical resource that determines productivity of the landscapes and availability of recreation opportunities like fishing and rafting. Understanding water resources, especially in a semi-arid region such as Colorado, is critical to effective planning efforts. The value and uncertainty surrounding this resource explain why these terms frequently occur within climate change passages.

"Vegetation" was also frequently mentioned within climate change passages and will be impacted by changes in precipitation and water availability. It impacts BLM planners' ability to allocate grazing permits, since capacity is dependent on production. Other disturbances and impacts related to climate change such as fire, insect outbreaks, rising temperatures, and droughts will alter vegetation composition and structure. Warmer temperatures and earlier spring snowmelt have already impacted vegetation across the Western USA, leading to a documented increase in large wildfire activity beginning in the mid-1980s: higher large wildfire frequency, longer wildfire duration, and longer wildfire season (Westerling et al., 2006). Changes in vegetation could have other repercussions throughout the ecosystem by affecting important ecosystem services such as water availability and quality, biodiversity, and wildlife habitat (Gordon \& Ojima 2015). The ecological functions of vegetation and the importance to wildlife and livestock explain why the term is mentioned frequently in the context of climate change within the planning documents. These findings show that BLM staff is considering hydrological and vegetation resources in the context of climate change. However, based on our findings surrounding climate change inclusion in planning documents, it is unlikely these passages contain an exploration of management strategies in response to climate change. 


\section{Climate-related impacts}

Water-related impacts, like "drought" and "flood," were frequently cited along with climate change, and underscore BLM concerns regarding changes in precipitation. These concerns make sense given the uncertainty associated with precipitation projections (Lukas et al. 2014), and the importance of water in natural resource management in semi-arid environments. Climate change science suggests impacts including generally lower stream flows throughout the summer months (CWCB 2015a; Lukas et al. 2014), increase in flooding (CWCB 2015b), and more frequent and intense drought (Gershunov et al. 2013; Lukas et al. 2014). Drought, in turn, will affect some of the other impacts commonly cited along with climate change in the gray literature, including more frequent and severe fires, insect outbreaks, and increase vulnerability of forests to insects and pathogens (Gordon \& Ojima 2015). These are some of the natural disturbances that have the greatest effect on forest health within the USA (Dale et al. 2001) and will also influence capacity for grazing permits, timing of recreation permits, and ecological health. Since managers need to understand these impacts for careful planning and response, it makes sense that they are talked about often in planning documents.

"Fire" was also frequently cited $(N=94)$ in the gray literature. The BLM manages 4.2 million acres of forested land in Colorado, primarily in the state's lower elevation piñon-juniper and oak shrubland forests (Colorado State Forest Service (CSFS), 2009). Forested acres account for nearly half of BLM land within Colorado and account for $17 \%$ of the total forested area of the state. Therefore, managing forests and the climaterelated impacts to them makes up a large part of their stewardship responsibilities. As wildfires increase in frequency, intensity, and severity, they pose a growing risk not only in terms of ecosystem damage and forest destruction but also to public safety/health and vulnerable infrastructure (Colorado Water Conservation Board (CWCB), 2015a). "Disease" $(N=28)$ and "insect" $(N=26)$ were also near the top of the list of climaterelated impact terms mentioned alongside climate change. The overlap of these terms with climate change passages highlights the importance of forest resources in Colorado and the agency's awareness of the threats to their health and structure.

\section{Land-based livelihoods and climate change}

Most co-occurrences of livelihood terms, like "grazing" and "recreation," pointed to passages where the BLM staff recognizes these as impacts, stressors, and even contributors to climate change. These interpretations are valid, as land-uses impact resources (Alkemade et al. 2013; Larson et al. 2016; Schieltz \& Rubenstein 2016), emit carbon dioxide (Grossi et al. 2019), and likely increase conflict and overall stress on resources (Froese \& Schilling 2019). However, our primary interest was how management might respond in order to support livelihoods in a changing context. The Colorado BLM recognizes the potential for climate change to impact resources and disturbance regimes, but does not extend these insights to impacts on land-based livelihoods or how the BLM might respond.

This finding is significant because the livestock and recreation industries are economically valuable to the state of Colorado. Cattle production (beef and dairy) in Colorado is a $\$ 3$ billion industry with an additional $\$ 112$ million from sheep and lamb (Gordon \& Ojima 2015). Impacts of rising temperatures on livestock include heat stress leading to reduced ability to gain weight, declining forage and soil quality, availability of feed supplies, and potential increase of parasites and diseases (Joyce et al. 2013). Livestock grazing is allowed on 7.8 million of the 8.5 million total acres they manage within Colorado (Bureau of Land Management, 2017b) making it a widespread land use. The Colorado BLM does address drought in their management plans and, in some cases, provides grazing management strategies under drought conditions to reduce degradation to rangelands. However, failure to consider impacts to land-based livelihoods holistically and adopt management strategies to address them may decrease the adaptive capacity of the industry in a changing climate.

Colorado's recreation industry also heavily depends on healthy natural resources and availability of snow and water. This makes the recreation and tourism industry, estimated to bring in between $\$ 8.5$ and $\$ 15$ billion annually in Colorado, particularly vulnerable to climate change (Gordon \& Ojima 2015; Thomas et al. 2013). For example, the projected decrease of average streamflow would have detrimental effects on rafting, fishing, and other water-based activities. Declines or shifts in the timing of streamflow would impact the outfitters whose livelihoods depend on the number of visitors and the reliability of the resource. Socio-economic impacts to ranching and recreationbased livelihoods would also reverberate into local communities.

One of the current DOI Secretary's top priorities includes "be [ing] a better neighbor with those closest to our resources" (Department of Interior (DOI), 2018b). A more specific discussion of how these public land-based livelihoods will be managed under a shifting climate would increase the adaptive capacity of these livelihoods and industries. For example, the BLM staff could work with their permittees to develop language that outlines the ways a field office might alter permit procedures in response to observed environmental changes as part of NEPA proceedings for future permits.

\section{Limitations}

The aim of this gray literature review has been to carefully and thoroughly review Colorado BLM field office planning 
documents and RAC meeting notes to understand how the BLM has integrated climate change into planning documents. Search terms were developed to help us systematically find and review the key passages. While explicit mentions of climate change were certainly captured, other more nuanced discussions of resources may have been missed. During the coding process, passages where the agency discusses management actions in response to natural ecosystem variability were observed. Systematically, coding these passages would have provided examples of how the BLM already handles uncertainty in management documents, but was beyond the scope of our analysis. Finally, the results of this review could benefit from follow-up interviews with field office managers and RMP authors to provide deeper insight into the nuanced ways that climate change is considered within the agency, but this was also outside the scope of our analysis.

\section{Conclusion: implications for Bureau of Land Management}

Reviewing planning documents has provided insight into how climate change is currently integrated. Although field offices that have most recently undergone the RMP revision process include a discussion of climate change in their PRMP/FEIS documents, there is little inclusion in the final RMP. Omitting specific management actions in response to climate change from planning documents may result in a blind spot for field offices when making management decisions. By acknowledging potential climate change-related impacts to resources in the RMP, field offices would be better equipped to consider the long-term outcomes of management actions.

Because climate change is a large-scale challenge, planning for it may be a daunting task to the local field offices. Topdown guidance from the Colorado BLM headquarters or the DOI could facilitate engagement with the issue. Agencies such as USFS and NPS that have defined guidance have shown greater incorporation of climate change into planning efforts (Archie et al. 2012). If planning staff and resource specialists look at potential impacts to their resources through the lens of a few plausible regional climate scenarios, then, climate change could be integrated in the development of the document. Because field offices lack climate science experts on staff, this could entail a BLM staff liaison between climate science experts and the field offices on a regular basis, but especially during the RMP revision process. Or, the BLM could adopt something like the USFS "Climate Change Performance Scorecard” (US Forest Service (USFS), 2011) and the online Climate Change Resource Center (www.fs. usda.gov/ccrc/) that help each forest unit plan and measure progress of climate change integration. However, top-down guidance on climate change is not being prioritized by the current administration as of this writing in 2019. Therefore, field offices interested in reducing their vulnerability to climate change and building adaptive capacity may need to be more proactive to ensure climate change is being considered in their planning documents.

Integration of AM language in RMPs would outline possible actions based on defined thresholds or specific impacts. BLM managers perceive that it is challenging to adopt AM in the NEPA process because exact actions or management directions will not always be clear (McNeeley et al. 2017b). However, there is precedent with adaptive drought management plans within the gray literature and AM plans within other agencies. Defined thresholds would need to be expanded beyond drought to include a more robust suite of impacts and resources. As new RMPs are developed, the previous climate scenarios can be revisited and resource projections, thresholds, and management direction can be refined.

If the RMP is not viewed as the appropriate place for this scale of planning in the face of uncertainty, there are other ways to integrate climate change preparedness into the culture and structure of the BLM field offices. For example, the state office could coordinate a standardized set of scenario planning workshops to ensure field office managers are empowered to address the topic when making management decisions. The state office could partner on this effort with the Climate Adaptation Science Center (CASC) in the North Central region, housed at the University of Colorado. Their mission, "to deliver science to help fish, wildlife, water, land, and people adapt to a changing climate," is well-aligned with the needs of the BLM, and facilitating communication between the two entities could increase the capacity and ability of the BLM to address climate change.

As climate change planning is developed, the vulnerability of land-based livelihoods should be considered in addition to ecological impacts to build a more complete understanding of complex social-ecological systems on multiple-use public lands (McNeeley et al. 2017a). The gray literature review reveals that there is currently little documented discussion of how climate change will potentially impact the livelihoods of those who depend on public land resources. Rather, this analysis reveals that planning documents focus on how these activities act as stressors on resources and have the potential to exacerbate the impacts of climate change. Nevertheless, people will be socially and economically impacted by how the BLM plans to respond and adapt to the impacts of climate change. If impacts to their livelihoods are not considered by field offices when making management decisions, it will be challenging for the BLM to maintain its multiple-use mission and stay abreast of potential management threats. For example, if grazing or recreation becomes unviable due to climate change impacts on public land, the BLM's revenue from permittees would be reduced; rural communities that house field offices could see serious economic impacts and surrounding 
private land changes could have major implications for the management of public lands.

If the BLM, as the stewards of 8.4 million acres of public lands in Colorado, desires to continue managing for multiple uses, they need to address climate change in their planning processes. How they plan for and adapt to the impacts of climate change will affect the health of ecosystems and determine what our landscape looks like in the decades to come. Whether they address it through their RMPs or through applied methods on the ground, integration of climate change will support informed and proactive management.

Acknowledgments The authors thank the Bureau of Land Management (L15AC00072) and the North Central Climate Science Center for supporting this research. The project described in this publication was supported, in part, by funding from the U.S. Geological Survey through the North Central Climate Science Center. The authors are particularly grateful to Bruce Rittenhouse for his support and guidance, as well as to John Gioia and Trevor Even for their contributions.

\section{Compliance with ethical standards}

Disclaimer The findings and perspectives remain those of the authors alone, and the contents of this paper are solely the responsibility of the authors and do not necessarily represent the views of the North Central Climate Science Center, the National Climate Change and Wildlife Science Center, or the USGS. This manuscript is submitted for publication with the understanding that the U.S. government is authorized to reproduce and distribute reprints for governmental purposes.

Open Access This article is licensed under a Creative Commons Attribution 4.0 International License, which permits use, sharing, adaptation, distribution and reproduction in any medium or format, as long as you give appropriate credit to the original author(s) and the source, provide a link to the Creative Commons licence, and indicate if changes were made. The images or other third party material in this article are included in the article's Creative Commons licence, unless indicated otherwise in a credit line to the material. If material is not included in the article's Creative Commons licence and your intended use is not permitted by statutory regulation or exceeds the permitted use, you will need to obtain permission directly from the copyright holder. To view a copy of this licence, visit http://creativecommons.org/licenses/by/4.0/.

\section{References}

Alkemade R, Reid RS, Van den Berg M, de Leeuw J, Jeuken M (2013) Assessing the impacts of livestock production on biodiversity in rangeland ecosystems. Proc Natl Acad Sci 110(52):20900-20905. https://doi.org/10.1073/pnas.1011013108

Archie KM, Dilling L, Milford JB, Pampel FC (2012) Climate change and western public lands: a survey of U.S. federal land managers on the status of adaptation efforts. Ecol Soc 17(4). https://doi.org/10. 5751/es-05187-170420

Bureau of Land Management (2017a) Resource advisory councils. BLM. https://www.blm.gov/get-involved/resource-advisory-council/ about-rac. Accessed 26 April 2017

Bureau of Land Management (2017b) Colorado rangeland management and grazing. BLM. https://www.blm.gov/programs/naturalresources/rangeland-and-grazing/rangeland-health/Colorado. Accessed 21 June 2017
Bureau of Land Management (BLM) (2015) Public land statistics 2015. Vol. 200:BLM/OC/ST- 16/003+1165 P-108-5. U.S. Department of the Interior. https://www.blm.gov/sites/blm.gov/files/documents/ files/Public\%20Land\%20Statistics2015\%20\%281\%29.pdf. Accessed 10 November 2018

Bureau of Land Management (BLM) (2016) Land use planning. BLM. https://www.blm.gov/wo/st/en/prog/planning/planning_overview. html. Accessed 30 March 2017

Canter L, Atkinson SF (2010) Adaptive management with integrated decision making: an emerging tool for cumulative effects management. Impact Assess Proj Apprais 28(4):287-297. https://doi.org/ $10.3152 / 146155110 \times 12838715793002$

Colorado State Forest Service (CSFS) (2009) Colorado statewide forest resource assessment: a foundation for strategic discussion and implementation of forest management in Colorado. Colorado State Forest Service. https://static.colostate.edu/client-files/csfs/pdfs/ SFRA09_csfs-forestassess-web-bkmrks.pdf. Accessed 25 June 2017

Colorado Water Conservation Board (CWCB) (2015a) Colorado climate plan: state level policies and strategies to mitigate and adapt. Colorado Water Conservation Board. https://www.colorado.gov/ pacific/sites/default/files/021518_REF_ColoradoClimatePlan.PDF. Accessed 15 March 2017

Colorado Water Conservation Board (CWCB) (2015b) Colorado's water plan: collaborating on Colorado's water future. Colorado Water Conservation Board. https://www.colorado.gov/pacific/ cowaterplan/plan. Accessed 10 March 2017

Council on Environmental Quality (CEQ) (2016) Fact sheet: White House council on environmental quality releases final guidance on considering climate change in environmental reviews. https:/ceq. doe.gov/docs/ceq-regulations-and-guidance/nepa_final_ghg guidance.pdf. Accessed 15 September 2016

Dale VH, Joyce LA, McNulty S, Neilson RP, Ayres MP, Flannigan MD, Hanson PJ, Irland LC, Lugo AE, Peterson CJ, Simberloff D, Swanson FJ, Stocks BJ, Wotton BM (2001) Climate change and forest disturbances: climate change can affect forests by altering the frequency, intensity, duration, and timing of fire, drought, introduced species, insect and pathogen outbreaks, hurricanes, windstorms, ice storms, or landslides. BioScience 51(9):723-734. https://doi.org/10.1641/ 0006-3568(2001)051[0723:CCAFD]2.0.CO;2

Department of Interior (DOI) 2009 Secretarial Order No. 3289, Addressing the impacts of climate change on America's water, land, and other natural and cultural resources, . https://www.fws.gov/home/ climatechange/pdf/SecOrder3289.pdf. Accessed 10 August 2019

Department of Interior (DOI) (2018a) Strategic plan for fiscal years 20182022. Department of Interior https://www.doi.gov/sites/doi.gov/ files/uploads/fy2018-2022-strategic-plan.pdf Accessed 21 July 2018

Department of Interior (DOI) (2018b) Secretary's 10 priorities. Department of Interior. https://www.blm.gov/basic/nationalpriorities. Accessed 25 August 2018

Eakin H, Luers AL (2006) Assessing the vulnerability of socialenvironmental systems. Annu Rev Environ Resour 31(1):365-394. https://doi.org/10.1146/annurev.energy.30.050504.144352

Executive Order (EO) (2009) No. 13514, Federal leadership in environmental, energy, and economic performance, 3 C.F.R. . https://www. fedcenter.gov/programs/eo13514/. Accessed 10 August 2019

Executive Order (EO) (2013) No. 13653, Preparing the United States for the impacts of climate change, 3 C.F.R.. https://www.federalregister. gov/documents/2013/11/06/2013-26785/preparing-the-unitedstates-for-the-impacts-of-climate-change. Accessed 10 August 2019

Executive Order (EO) (2015) No. 13693, Planning for federal sustainability in the next decade, 3 C.F.R. . https://www.fedcenter.gov/ programs/eo13693/. Accessed 10 August 2019 
Federal Land Policy Management Act (FLPMA) of 1976 (1976) 43 U.S.C. §102. https://www.blm.gov/or/regulations/files/FLPMA. pdf. Accessed 10 August 2019

Frankson R, Kunkel K, Stevens L, Easterling D (2017) 2017: Colorado state climate summary. NOAA Technical Report NESDIS 149-CO: 4 pp. https://statesummaries.ncics.org/chapter/co/

Froese R, Schilling J (2019) The nexus of climate change, land use, and conflicts. Current climate change reports 5(1):24-35. https://doi.org/ 10.1007/s40641-019-00122-1

Gershunov A, Rajagopalan B, Overpeck J, Guirguis K, Cayan D, Hughes M, Dettinger M, Castro C, Schwartz RE, Anderson M, Ray AJ, Barsugli J, Cavazos T, Alexander M (2013) Future climate: projected extremes. In: Garfin G, Jardine A, Merideth R, Black M, LeRoy S (eds) Assessment of climate change in the southwest United States: a report prepared for the national climate assessment. Island Press, Washington, DC, pp 126-147. https://doi.org/10.5860/ choice.51-1504

Gonzalez P, Garfin GM, Breshears DD, Brooks KM, Brown HE, Elias EH, Gunasekara A, Huntly N, Maldonado JK, Mantua NJ, Margolis HG, McAfee S, Middleton BR, Udall BH (2018) Southwest. In: Reidmiller DR, Avery CW, Easterling DR, Kunkel KE, Lewis KLM, Maycock TK, Stewart BC (eds) Impacts, risks, and adaptation in the United States: fourth national climate assessment,volume II. U.S. Global Change Research Program, Washington, DC, pp 1101-1184. https://doi.org/10.7930/NCA4.2018.CH25

Gordon E, Ojima D (2015) Executive summary. In: Gordon E, Ojima D (ed) Colorado climate change vulnerability study. University of Colorado, Boulder, CO and Colorado State University, Fort Collins, CO, pp i-vii. https://wwa.colorado.edu/climate/ co2015vulnerability/co_vulnerability_report_2015_final.Pdf. Accessed 12 August $201 \overline{9}$

Grossi G, Goglio P, Vitali A, Williams AG (2019) Livestock and climate change: impact of livestock on climate and mitigation strategies. Animal Frontiers 9(1):69-76. https://doi.org/10.1093/af/vfy034

Holling CS (1978) Adaptive environmental assessment and management. Chichester: Wiley. http://pure.iiasa.ac.at/823. Accessed 25 June 2018

Joyce LA, Briske DD, Brown JR, Polley HW, McCarl BA, Bailey DW (2013) Climate change and North American rangelands: assessment of mitigation and adaptation strategies. Rangel Ecol Manag 66:512 528. https://doi.org/10.2111/rem-d-12-00142.1

Kemp K, Blades J, Klos PZ, Hall T, Force JE, Morgan P, Tinkham W (2015) Managing for climate change on federal lands of the western United States: perceived usefulness of climate science, effectiveness of adaptation strategies, and barriers to implementation. Ecol Soc 20(2). https://doi.org/10.5751/es-07522-200217

Knapp C, Fernandez-Gimenez ME, Briske DD, Bestelmeyer BT, Wu XB (2011) An assessment of state-and-transition models: professionals' perceptions following two decades of development and implementation. Rangel Ecol Manag 64(6):598-606. https://doi.org/10.2111/ REM-D-10-00188.1

Larson CL, Reed SE, Merenlender AM, Crooks KR (2016) Effects of recreation on animals revealed as widespread through a global systematic review. PLoS One 11(12). https://doi.org/10.1371/journal. pone.0167259

Lukas J, Barsugli J, Doesken N, Rangwala I, Wolter K (2014) Climate change in Colorado: a synthesis to support water resources management and adaptation. Prepared for the Colorado Water Conservation Board by the Western Water Assessment, Cooperative Institute for Research in Environmental Sciences (CIRES), and University of Colorado, Boulder. https://wwa.colorado.edu/climate/
co2014report/Climate_Change_CO_Report_2014_FINAL.pdf. Accessed 23 July 2019

McNeeley SM, Even TL, Gioia JB, Knapp CN, Beeton TA (2017a) Expanding vulnerability assessment for public lands: the social complement to ecological approaches. Clim Risk Manag 16:106-119. https://doi.org/10.1016/j.crm.2017.01.005

McNeeley SM, Knapp C, Even T, Gioia J, and Nave J (2017b) Colorado Bureau of Land Management: social vulnerability assessment, final report. Natural Resource Ecology Laboratory, Colorado State University, Fort Collins, CO. https://cnhp.colostate.edu/projects/ climate-change/\#COBLM. Accessed 13 August 2019

National Park Service (NPS) (2010) National Park Service climate change response strategy. National Park Service Climate Change Response Program, Fort Collins, Colorado. https://www.nature. nps.gov/climatechange/docs/NPS_CCRS.pdf. Accessed 25 June 2018

National Park Service (NPS) (2012) National Park Service climate change action plan 2012-2014. National Park Service Climate Change Response Program, Fort Collins, Colorado. https://www. nps. gov/subjects/climatechange/upload/Jan Feb Mar 2013News. pdf. Accessed 25 June 2018

National Park Service (NPS) (2016) Winter use adaptive management program. Yellowstone National Park Adaptive Management Program. https://www.nps.gov/yell/learn/management/wuamp.htm. Accessed 25 June 2018

Reidmiller DR, Avery CW, Easterling DR, Kunkel KE, Lewis LMR, Maycock TK, Stewart BC (2018) Impacts, risks, and adaptation in the United States: fourth national climate assessment, volume II. U.S. Global Change Research Program, Washington, DC. https:// doi.org/10.7930/NCA4.2018.CH1

Schieltz JM, Rubenstein, DI (2016) Evidence based review: positive versus negative effects of livestock grazing on wildlife. What do we really know? Environmental Research Letters, 11(11). doi: https:// doi.org/10.1088/1748-9326/11/11/113003

Shear MD (2017) Trump will withdraw U.S. from Paris climate agreement. The New York Times. https://www.nytimes.com/2017/06/01/ climate/trump-paris-climate-agreement.html. Accessed 10 July 2018

State of Colorado (2017) Historic tribes of Colorado. State of Colorado. https://www.colorado.gov/ pacific/ccia/historic-tribes-colorado. Accessed 22 November 2018

Thomas DSK, Wilhelmi OV, Finnessey TN, Deheza V (2013) A comprehensive framework for tourism and recreation drought vulnerability reduction. Environ Res Lett 8. https://doi.org/10.1088/17489326/8/4/044004

Trump DJ (2017) National security strategy. Washington, DC: White House. https://www.whitehouse. gov/wp-content/uploads/2017/12/ NSS-Final-12-18-2017-0905.pdf. Accessed 15 July 2018

US Forest Service (USFS) (2009) Considering climate change in land management and project planning. USFS Washington Office. https://www.fs.fed.us/emc/nepa/climate_change/index.htm. Accessed 26 June 2018

US Forest Service (USFS) (2011) Navigating the climate change performance scorecard: a guide for National Forests and grasslands (Version 2). USDA Forest Service. https://www.fs.fed.us /climatechange/advisor/scorecard/scorecard-guidance-08-2011.pdf. Accessed 10 August 2019

US Forest Service (USFS) (2015) The rising cost of wildfire operations: effects on the Forest Service's non-fire work. USDA Forest Service. https://www.fs.fed.us/sites/default/files/2015-Rising-Cost-WildfireOperations.pdf. Accessed 25 October 2017 
US Forest Service (USFS) (2016) Spruce beetle epidemic and aspen decline management response final record of decision. USFS GMUG National Forests. https://www.fs.usda.gov/nfs/11558/ www/nepa/96623_FSPLT3_3802025.pdf. Accessed 27 June 2018

US Forest Service (USFS) (2017) Maroon Bell-Snowmass Wilderness Area overnight visitor use management plan environmental assessment. White River National Forest. https://www.fs.usda.gov/nfs/ 11558/www/nepa/104254_FSPLT3_4032620.pdf. Accessed 28 June 2018

US Geological Survey (USGS) (1990) Largest river in the United States. USGS Water Resources Division. http://pubs.usgs.gov/of/1987/ ofr87-242/pdf/ofr87242.pdf. Accessed 9 March 2017

Vincent CH, Hanson LA, Argueta CN (2017) Federal land ownership: overview and data. Congressional Research Service 42346. https:// fas.org/sgp/crs/misc/R42346.pdf
Westerling AL, Hidalgo HG, Cayan DR, Swetnam TW (2006) Warming and earlier spring increase western US forest wildfire activity. Science 313(5789):940-943. https://doi.org/10.1126/science. 1128834

Wiles T, Warren B (2016) Federal-lands ranching: a half-century of decline. High Country News. https://www.hen.org/issues/48.10/ federal-lands-grazing. Accessed 25 July 2018

Publisher's note Springer Nature remains neutral with regard to jurisdictional claims in published maps and institutional affiliations. 